\title{
Consumer Brand Preference in Buying Car in Nepal
}

\author{
Bharat Rai ${ }^{1}$
}

\begin{abstract}
The main objective this study is to identify the factors affecting the consumer brand preference in the choice of car in Kathmandu, Nepal. The study examines how the price perception, appearance perception and brand personality affect in the consumer brand preference in the buying of car in Nepalese market. The study focuses on how the consumer preferred to select the car and which factor has the more prominent role for brand preference and selection of car. Primary data has been used in the study. The structured questionnaire has been used for collection of primary data. Convenient sampling technique has been used to collect information from the respondents and 265 respondents have been taken from customers buying car in Kathmandu. Descriptive statistical analysis, correlation analysis and path analysis have been used to diagnose data collected to draw valid conclusions using SPSS AMOS 21. Price perception, appearance perception and brand personality are taken as independent variables to explore the degree of relationship with consumer behavior and to explore the impact of these variables on consumer behavior while making decision to purchase a car. Correlation showed that all independent variables have significant relationship with dependent variable. The path analysis showed that there is a significant impact of appearance perception and brand personality on consumer behavior in buying of car but price perception has no significant impact on consumer behavior in buying of car in Nepalese market.
\end{abstract}

Key words: Consumer Brand Preference, Price Perception, Appearance Perception, Brand Personality, Car

\section{Background of the study}

Brand preference is the level of like and dislike of consumers towards the specific brand. The consumer's preference for a brand is a function of his/her cognitive beliefs about the brand's weighted attributes.

Horsky et al. (2006) demonstrate the importance of incorporating information about brand preference into the brand choice model. Brand preferences represent consumer dispositions to favour a particular brand (Overby \& Lee, 2006). It refers to the 1 Mr. Rai is a lecturer of Management at Nepal Commerce Campus, Minbhawan, Kathmandu, T. U. 
behavioral tendencies reflecting the extent to which consumers favor one brand over another (Hellier et al., 2003).

Brand preference is an essential step in understanding consumer brand choice; has therefore, always received great attention from marketers. Brand preference is close to reality in terms of reflecting consumer evaluation of brands. In the marketplace, consumers often face situations of selecting from several options (Dhar, 1999).

Brand is a distinguishing feature of a product and is often important to customers purchasing the product. Consumer preferences for brands reflect three responses: cognitive, affective and conative or behavioral (Grimm, 2005). The cognitive components encompass the utilitarian beliefs of brand elements (Bagozzi, 1982; Grimm, 2005: Zajonc \& Markus, 1982). The affective responses refer to the degree of liking or favoring that reflects consumer feelings towards the brand (Grimm, 2005). The conative or behavioral tendencies are denoted by Zajonc \& Markus (1982) as the consumers' predicted or approached act towards the object. It is the revealed preference exhibited in consumers' choices.

Changes in consumer brand preferences are reflected on the brand performance and market shares (Sriram et al., 2006). In addition, brand preference combines the desired attributes and consumer perceptions; thus, it offers an indirect and unobtrusive way to assess salient attributes (Keller, 1993; O'Connor and Sullivan 1995; Schoenfelder $\&$ Harris, 2004). Therefore, uncovering consumer brand preferences are considered critical input to design successful brand strategy, brand positioning, and gives insights to product development (Alamro \& Rowley, 2011; Alamro, 2010; Horsky et al., 2006). Consequently, understanding brand preferences contributes in building strong brands able to build long-term relationship with consumers.

Brand preference is the extent to which the customer favors the designated service provided by a certain company, in comparison to the designated service provided by other companies in his or her consideration set. $\square$ Preferences facilitate consumers' choice by enhancing their intentions towards the favored brand. Actual purchasing behavior is likely to correspond to intentions; the mechanism of intention formation provides evidence of persistent consumer preferences (Van Kerckhove et al., 2012). The consistency between consumer preferences and choices adds to the predictive validity of preference statement over attitude (Bither \& Wright, 1977; Hellier et al., 2003). Cobb-Walgren et al., (1995) reported that attitude is a poor indicator of consumer behavior in the marketplace. 


\section{Research Objectives}

The general research objective of the study is to understand how consumers prefer the brand.

The specific objectives of this research are as follows;

- To examine the impact of price perception on brand preference in the buying of car.

- To examine the impact of brand personality on brand preference in the buying of car.

- To examine the impact of product appearance perception on brand preference in the buying of car.

\section{Theoretical Framework}

There are various factors which influence in the brand preference like price, brand, features, brand personality, salesmanship, brand appearance, self-congruity, and intangible attributes etc. From the above literature review the researcher has been taken only three variables like price perception, appearance perception and brand personality as independent variables to identigy the impact on brand preference in the study.

The theoretical framework of the study is presented as below;

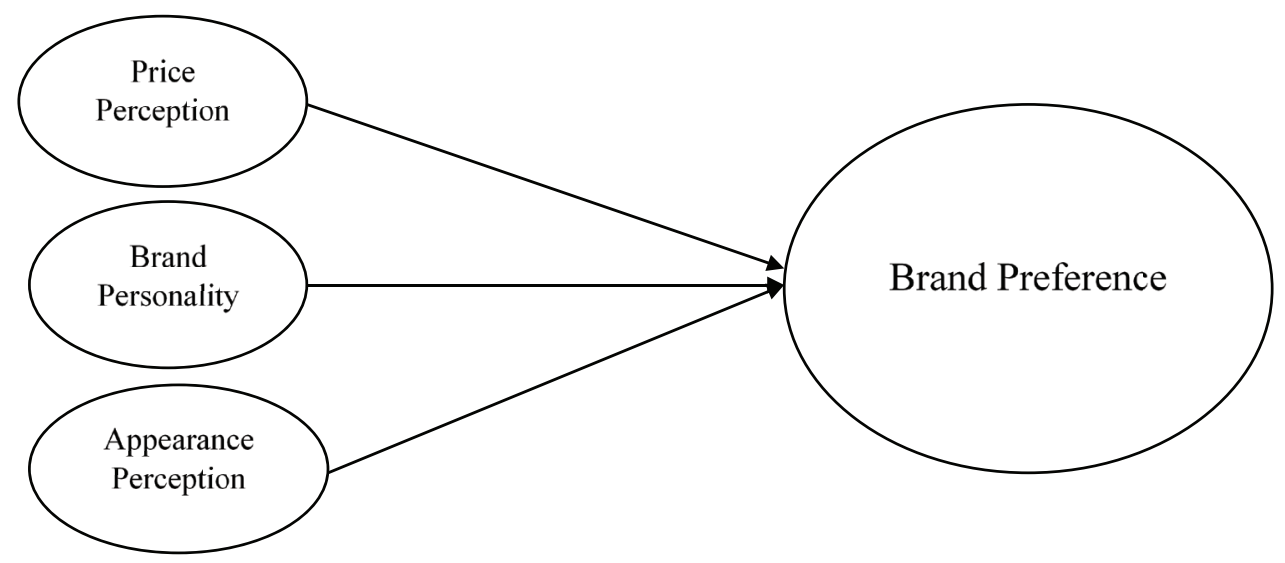

Figure 1: Conceptual Framework 


\section{Research Hypothesis}

On the basis of above theoretical framework the followings hypotheses are determined;

H1: There is significant impact of price perceptions on brand preference in buying of car.

H2: There is significant impact of brand personality on brand preference in buying of car.

H3: There is significant impact of appearance perceptions on brand preference in buying of car.

\section{Literature Review}

Price is the exchange value of goods and service and it is paid for getting goods and services. Price is an important factor in brand purchase and consumer choice (Erdem et al., 2006). The economist's assumption of rationality conceives price as an aspect of consumer rationality where (Mc Fadden, 1999) stated those rational consumers who focus on tangible brand attributes assign greater importance to price than irrational consumers; price remains an important positive or negative cue in consumer behavior (Lichtenstein et al., 1993). So, there is positive and negative influence of price on consumer behavior. The role of price as an independent factor on consumer brand preferences has been demonstrated (Alamro \& Rowley, 2011; Schoenfelder \& Harris, 2004). In experiential marketing, price is the cost of delivered experiences and the consumer's perceptions of price fairness, which contribute to his/her, experience (Brakus et al., 2009). Pine and Gilmore (1998) presume that the product price contributes to the creation of consumer experience. The authors suggest that the consumer price experience can be considered as a progression of the economic value (Pine \& Gilmore, 1998; Schmitt, 1999), or that the traditional mix of price and quality goes beyond money (Mathwick et al., 2001). Consumers may be willing to pay a premium for the brand experience, but not its cost (Pine \& Gilmore, 1998; Verhoef et al., 2009).

Empirically, the price of service positively affects the consumer experience in hospitality marketing (Ismail, 2010). Moreover, Verhoef et al. (2009) consider price as an important stimulus of consumer experience in a retailing context. For economists, consumers assign high weight to price compared with other attributes when evaluating alternatives to make a buying decision (McFadden, 1996). Zeithmal (1998) states that consumers' attention and weighing to price increase with high price products (Zeithmal, 1988). Consumers tend to pay high prices for brands perceived to have high value (Erdem et al., 2004). There is a general belief that consumers perceive price as an indicator of quality and quality influence for the brand preference. 
The aesthetic value of product is called product appearance. Appearance is a non-productrelated attribute (Keller, 1993); it is hedonic (Chitturi, et al., 2008; Lee et al., 2011) or symbolic (Creusen \& Schoormans, 2005). Value is derived from consumer beliefs on the brand's aesthetic appeal. This reflects the beauty of the brand designs and sensory attributes (Reimann et al., 2010; Sheng \&Teo, 2012; Veryzer, 1993). Brand appearance is a source of pleasure (Decker \&Trusov, 2010; Petruzzellis, 2010; Schoenfelder\& Harris, 2004; Veryzer $\&$ Hutchinson, 1998) and a significant differentiating attribute that enhances consumer preferences (Reimann et al., 2010). Brand preference is based on appearance of the product.

The word aesthetic refers to the beauty or art of design, and retains the affect and pleasure created from the consumers' responses to the physical features or design of the brand (Veryzer, 1993). Appearance is not part of the necessary ingredients required for product performance. Appearance perception is a symbolic benefit derived from consumer beliefs about the aesthetic appeal of the brand (Chitturi et al., 2008; Lee et al., 2011). The brand aesthetic enhances consumer senses (Hulten, 2011; Schmitt, 1999), and affects their experiential responses (Gentile et al., 2007) Research findings support the notion that the consumer's perception of the brand appearance or aesthetic is associated with his/her experiences (Sheng \&Teo, 2012). Consumers allocate more importance to the hedonic attributes and are even willing to pay more when they choose between brands with equal utilitarian attributes (Chitturi et al., 2007). The hedonic attributes build strong brands, are distinguishable from those of competitors and induce positive impressions in consumers (Chitturi et al., 2007; 2008; Lee et al., 2011). The visual appearance not only increases the aesthetic attractiveness, but also affects the usability as quality indicators (Rondeau, 2005; Sheng \&Teo, 2012). Recently, empirical evidence from academic research supports the positive impact of the aesthetic or appearance perception on consumer experiences in a different context, such as online branding (Sheng \&Teo, 2012).

Kepferer (2008) defines brand identity as the brand meaning the company delivers to the target consumers. Brand personality is an important component in the brand identity prism constructive source. Brand personality is the second factor of brand association. It is based on symbolic perspective and should be discussed separately from other associations (Aaker, 1996). In the marketing literature, there is an overlap between the terms of brand identity, brand image and brand personality but the band personality is the one part of band image.

Keller (1993) defines brand image as the brand perceptions of the consumer. The brand image refers to the brand's functional and symbolic benefits (Low \& Lamb, 2000), while the brand personality refers only to the brand's symbolic associations (Keller, 1993). 
Therefore, Plummer (2000) considers brand personality as an important component of the brand image. He defines the brand personality as the symbolic meaning of the brand linked to the non-related brand attributes.

The personality traits consumers assign to the brand are influenced by direct and indirect contact with the brand (Aaker, 1997; Heding et al., 2009). The personality of the brand originated from the brand image, brand attributes and the associated traits consumers assign to the brand (Lin, 2010). The direct contact is between the consumer and the stereotypical brand user, company employees, the CEO or brand endorsers, while the indirect contact is between the consumer and the brand tangible or intangible attributes. Aaker (1997) was among the first to provide a solid definition of brand personality, referring to it as "the set of human characteristics associated with a brand". Brand personality means humanizing the brand (Swaminathan et al., 2009). It reflects how people feel about the brand, rather than how they think of the brand (Keller, 1993). These models describe the personality traits perceived by consumers rather than brands (Phau\& Lau, 2000). The most predominated definition and scale of brand personality in the marketing studies is that given by Aaker (1997); however, it has been criticized.

Practitioners have viewed brand personality as an efficient way to differentiate between competing brands. Therefore, it can enhance the marketing effectiveness (Heding et al., 2009), increase consumers' preferences for brands (Aaker, 1997; Biel, 1993; Fournier, 1998) and affect consumer judgments (Biel, 1992). The brand personality metaphor helps managers understand deeply consumer perceptions and attitudes towards the brand (Aaker, 2002). Plausibly, consumers organize the structure of brand knowledge in his mind and recall the functional benefit of the brand using salient brand personality (Zentes et al., 2008).

Aaker (1997) stated that brand personality information could be used as a heuristic cue and influence consumer attitude toward the brand. The appealing personality of the brand emphasizes the functional benefits of the brand, and helps consumers to express themselves. Thus, it results in favorable behavioral responses. In hospitality marketing, Kim et al. (2011) support the significant direct impact of brand personality on customers' preferences for restaurants. Consumer favorable perceptions for the brand personality affect the brand preferences (Phau \& Lau, 2000).

Evidence from prior studies supports the positive influence of brand personality on consumers' purchase intentions (Ward et al., 1999). In addition, brand personality can directly affect the consumer-brand relationship (Chang \&Chieng; 2006; Fournier, 1998), attitudinal loyalty (Kim et al., 2011), brand trust and attitude (Folse et al., 2012), brand affect (Sung \& Kim, 2010) and brand equity (Folse et al., 2012). 


\section{Research Methodology}

Research methodology is the future methods and procedures of research work it should be followed by researcher during the course of research work. Research methodology consists of types of research design, determination of population and sample, sampling process, determination of source of data, types of data, data collection procedures and analytical tools to be used to analyze the collected data.

The research design of the study is descriptive and explanatory on primary data. Using survey methodology, structured 5 point Likert scale questionnaires on each dependent and independent variables have been administered to obtain responses from car users in Nepalese market.

The sampling location for the research is allocated in show room, colleges and houses in Kathmandu. Convenient sampling method has been used in the study. 265 respondents are taken as a sample size of the study from car users.

Primary data has been used from car users in Nepalese market and it is collected through structured questionnaire. The population in the study is the consumers who will purchase the car in Nepalese market and who are residents of Kathmandu valley.

Descriptive and inferential statistics have been used to analyze the collected data. Collected data has been analyzed by using mean, standard deviation to describe the consumers' band preferences. Pearson Correlation Coefficient and Path Analysis have been used to find out relationships between antecedent's factors and brand preference and influence of these independent factors on brand preference.

\section{Data Analysis}

The collected data has been analyzed by descriptive and correlation analysis.

Table 1: Descriptive and Correlation Analysis

\begin{tabular}{lcccccc}
\hline & Mean & SD & PP & AP & BP & BPR \\
\hline PP & 3.496 & 0.567 & 1 & & & \\
AP & 3.950 & 0.482 & 0.462 & 1 & & \\
BP & 3.634 & 0.454 & 0.603 & 0.612 & 1 & \\
BPR & 3.814 & 0.452 & 0.43 & 0.545 & 0.678 & 1 \\
\hline
\end{tabular}

The table no, 1 indicates that descriptive statistics of brand preference in the buying car in Nepal. The questionnaire was design in the five point likert scale by indicating $1=$ strongly disagree, $2=$ disagree, $3=$ midpoint unsure (neutral) $4=$ indicates agree and $5=$ indicates 
strongly agree. The result has shown the mean score of consumer brand preference, price perception, appearance perception and brand personality are 3.81, 4.50, 3.95 and 3.63 respectively. All the respondents are inclined towards the brand preference. It shows that all respondents are agreed or strongly agreed towards the brand preference for buying of car. Thus, it can be concluded that the consumers are agree with the statements that price perception, appearance perception and brand personality have significant influence on consumer brand preference while purchasing the car products in the Nepalese markets.

Likewise, the standard deviations have been recorded as ranging from 0.452 to 0.567 which are consistent. It shows that the variability of collected data is significant to be used for the purpose of study.

As well as the above table describes about correlation matrix between variables under investigation. It shows that there is positive correlation between price perception and brand preference $(\mathrm{r}=0.43, \mathrm{p}<0.05)$, appearance perception and brand preference $(\mathrm{r}$ $=0.545, \mathrm{p}<0.05)$ and brand personality and brand preference $(\mathrm{r}=0.678, \mathrm{p}<0.05)$ in consumer buying car in Nepal. There is positive and significant relationship between independent variables (price perception, appearance perception, brand personality) and brand preference because the $p$ values of all variables are less than 0.05 . But there is low correlation between price and brand preference is low and the correlations between appearance perception and brand personality with brand preference are high.

Table 2: Path Analysis

\begin{tabular}{lcc}
\hline Hypothesis & Beta & Sig. \\
\hline $\begin{array}{l}\text { H1: There is significant impact of price perception on brand } \\
\text { preference. }\end{array}$ & 0.002 & 0.979 \\
$\begin{array}{l}\text { H2: There is significant impact of appearance perception on } \\
\text { brand preference. }\end{array}$ & 0.198 & $0.026^{*}$ \\
$\begin{array}{l}\text { H3: There is significant impact of brand personality on brand } \\
\text { preference. }\end{array}$ & 0.552 & $0.000^{* *}$ \\
\hline
\end{tabular}

The impact of all independent variables like price perception, appearance perception and brand personality is tested together on dependent variable (brand preference).

The table 2 describes about the path analysis. Two variables i.e. appearance perception ( $b$ $=0.198, \mathrm{p}<0.05)$ and brand personality $(\mathrm{b}=0.552, \mathrm{p}<0.05)$ have significant impact on consumer brand preference in buying car in Nepal. But, price perception $(b=0.002, p>0.05)$ has not significant impact on consumer brand preference towards buying car in Nepal. 


\section{Conclusions}

In this research, three important variables were chosen to investigate their effect on the brand preference. Price perception, brand personality and product appearance are taken as independent variables to explore the relationship with brand preference and to examine the impact on brand preference. Correlation analysis showed that all the three independent variables like price perception, appearance perception and brand personality have significant relationship with the dependent variable brand preference. In the study, regression analysis was conducted to explore the impact of independent variables like price perception, appearance perception and brand personality on brand preference. The result showed that the independent variables like appearance perception and brand personality have the significant effect on brand preference and the price perception has not significant impact on brand preference.

So, it is concluded that the price is not to be considered in the selling of car in the Nepalese market and the product appearance and brand personality has the prominent role in the brand preference, so it must be considered in selling of car.

\section{References}

Aaker, D. A. (1996). Measuring brand equity across products and markets, California. Management Review, 38(3), 102-120.

Aaker, D. A. (2002). Building Strong Brands, Free Press Business.

Aaker, J. L. (1997). Dimensions of brand personality. Journal of Marketing Research, 34(3), 347-356.

Alamro, A. (2010). Branding and brand preference in the mobile phone service industry, $P h D$ thesis, Bangor University.

Bagozzi, R. P. (1982). A field investigation of causal relations among cognitions, a $\square$ ect, intentions, and behavior. Journal of Marketing Research, 19(4), 562-683.

Bass, F. M., \&Talazyk, W.W. (1972). An Attitude Model for the Study of Brand Preference. Journal of Marketing Research, 9(1), 93-96.

Berry, L. L., Carbone, L. P., \& Haeckel, S. H. (2002). Managing the total customer experience. MIT Sloan Management Review, 43(3), 85-89.

Biel, A. L. (1992). How brand images drives brand equity. Journal of Advertising Research, 32(6), 6-12. 
Bither, S.W. \& Wright, P. (1977). Preferences between product consultants: choices vs. preference functions. Journal of Consumer Research, 4(1), 39-47.

Brakus, J. J., Schmitt, B. H., \& Zarantonello, L. (2009). Brand experience: What is it? How is it measured? Does it a $\square$ ect loyalty? Journal of Marketing, 73(3), 52-68.

Chang, H. H., \& Liu, Y. M. (2009). The impact of brand equity on brand preference and purchase intentions in the service industries. Service Industries Journal, 29(12), 1687-1706.

Chang, P. L.. \& Chieng, M. H. (2006). Building consumer-brand relationship: A crosscultural experiential view, Psychology and Marketing, 23(11), 927-959.

Chitturi, R., Raghunathan, R., \& Mahajan, V. (2007). Form versus function: how the intensities of specific emotions evoked in functional versus hedonic trade-offs mediate product preferences. Journal of Marketing Research, 44(4), 702-714.

Chitturi, R., Raghunathan, R., \& Mahajan, V. (2008). Delight by design: The role of hedonic versus utilitarian benefits. Journal of Marketing, 72, 48 -63.

Churchill, G. A. (1995) Marketing Research: Methodological Foundations, 6thedn, Dryden Press, New York.

Creusen, M. E. H., \&Schoormans, J. P. L. (2005). The di $\square$ erent roles of product appearance in consumer choice. Journal of Product Innovation Management, 22, 63 -81.

Czellar, S. (2003). Consumer attitude toward brand extensions: an integrative model and research propositions.International journal of Research in Marketing, 20(1), 97115.

Dhar, R. \& Novemsky, N. (2008). Beyond rationality: The content of preferences. Journal of Consumer Psychology, 18(3), 175-178.

Dhar, R., Nowlis, S. M., \& Sherman, S. J. (1999). Comparison effects on preference construction. Journal of Consumer Research, 26(3), 293-306.

Erdem, T., Swait, J., \& Valenzuela, A. (2006). Brands as signals: A cross-country validation study. Journal of Marketing, 70(1), 34-49.

Erdem, T., Zhao, Y., \& Valenzuela, A. (2004). Performance of store brands: A crosscountry analysis of consumer store-brand preferences, perceptions, and risk. Journal of Marketing Research, 41(1), 86-100.

Folse. J. A. G., Netemeyer, R. G. \& Burton, S. (2012). How the personality traits of sincerity, excitement, and competence help to build equity. Journal of Advertising, 41(1), 17-32. 
Fournier, S. (1998). Consumers and their brands: Developing relationship theory in consumer research. Journal of Consumer Research, 24(4), 343-373.

Gentile, C., Spiller, N., \&Noci, G. (2007). How to sustain customer experience: An overview of experience components that create value with the customer. European Management Journal, 25 (5), 395-410.

Heding, T., Knudtzen, C. F., \& Bjerre, M. (2009). Brand Management, Research, Theory and Practice, Routledge.

Hellier, P. K., Geursen, G. M., Carr, R. A., \& Rickard, J. A. (2003). Customer repurchase intention: A general structural equation model. European Journal of Marketing, 37(11/12), 1762-1800.

Holbrook, M. B., \& Hirschman, E. C. (1982). The experiential aspects of consumption: Consumer fantasies, feeling, and fun. Journal of Consumer Research, 9(2), 132-140.

Horsky, D., Misra, S., \& Nelson, P. (2006). Observed and unobserved preference heterogeneity in brand-choice models. Marketing Science, 25(4), 322-335.

Hulten, B. (2011). Sensory marketing: The multi-sensory brand-experience concept. European Business Review, 23(3), 256-273.

Ismail, A. R. (2010). Investigating British customers' experience to maximize brand loyalty within context of tourism in Egypt: Netnography\& structural modelling approach (Published thesis). London: Brunel University.

Kapferer, J. N. (2008). The New Strategic Brand Management: Creating and Sustaining Brand Equity Long Term, Kogan Page, US.

Keller, K. L. (1993). Conceptualizing, measuring, and managing customer-based brand equity. Journal of Marketing Research, 57(1), 1-22.

Kim, D., Magnini, V. P., \&Singal, M. (2011). The effects of customers' perceptions of brand personality in causal theme restaurants. International Journal of Hospitality Management, 30(2), 448-458.

Kotler, P., \& Armstrong, G. (2010). Principles of Marketing. New Jersey: Pearson Prentice Hall.

Lee, S., Ha, S., \& Widdows, R. (2011). Consumer responses to high-technology products: Product attributes cognition and emotions. Journal of Business Research, 64, 1195-1200. 
Lichtenstein, D. R., Ridgway, N., \& Netemeyer, R. G. (1993). Price perceptions and consumer shopping behavior: A field study. Journal of Marketing Research, $30(2), 234-245$.

Lin, L. Y. (2010). The relationship of consumer personality trait, brand personality and brand loyalty: an empirical study of toys and video games buyers. Journal of product and Brand Management, 19(1), 4-17.

Low, G. S., \& Lamb, C.W. (2000). The measurement and dimensionality of brand associations. Journal of Product and Brand Management, 9(6), 350-368.

Mathwick, C., Malhotra, N., \& Rigdon, E. (2001). Experiential value: Conceptualization, measurement and application in the catalog and internet-shopping environment. Journal of Retailing, 77(1), 39-56.

McFadden, D. (1996). Rationality for economists. Journal of Risk and Uncertainty, 19(1), 73-105.

O'Connor, P. J., \& Sullivan, G. L. (1995). Market segmentation: A comparison of benefits/attributes desired and brand preference. Psychology and Marketing, 12(7), 613635.

Oliver, R. L. (1999). Whence consumer loyalty? Journal of Marketing, 63(4), 33-44.

Osman, M. A., Talib, A. Z., Sanusi, Z. A., Shiang-Yen, T., \& Alwi, A. S. (2012). A Study of the Trend of Smartphone and Its Usage Behavior In Malaysia. International Journal of New Computer Architectures and Their Applications (IJNCAA), 2(1), 274-285.

Overby, J. W.. \& Lee, E. J. (2006). The effect of utilitarian and hedonic online shopping value on consumer preference and intentions. Journal of Business Research, 59(10), 1160-1166.

Palmer, A. (2010). Customer experience management: A critical review of an emerging idea. Journal of Services Marketing, 24(3), 196-208.

Phau, I., \& Lau, K. C. (2000). Conceptualizing brand personality: A review and research propositions. Journal of Targeting, Measurement and Analysis for Marketing, 9(1), 52-69.

Pine, B., \& Gilmore, J. H. (1998). Welcome to the experience economy. Harvard Business Review, (July-August), 97-105. Retrieved from http://rushkolnik.ru/ tw_files/4995/d-4994348/7z-docs/4.pdf 
Reimann, M., Zaichkowsky, J., Neuhaus, C., Bender, T., \& Weber, B. (2010). Aesthetic package design: A behavioral, neural, and psychological investigation. Journal of Consumer Psychology, 20(4), 431-441.

Rondeau, D. B.(2005). For mobile applications, branding is experience. Communications of the ACM, 48(7), 61-66.

Rose, S., Hair, N., \& Clark, M. (2011). Online customer experience: A review of the business to consumer online purchase context. International Journal of Management Reviews, 13(1), 24-39.

Schiffman, L. G., \& Kanuk, L. L. (2000). Consumer Behavior (7th Ed.). Wisconsin: Prentice Hall.

Schmitt, B. (1999). Experiential marketing. Journal of Marketing Management, 15(1-3), $53-67$.

Schmitt, B. (2009). The concept of brand experience. Journal of Brand Management, $16,417-419$.

Schoenfelder, J., \& Harris, P. (2004). Hightech corporate branding: lessons for market research in the next decade. Qualitative Market Research: An International Journal, (2), 91-99

Sheng, M. L., \&Teo, T. S. H. (2012). Product attributes and brand equity in the mobile domain: The mediating role of customer experience. International Journal of Information Management, 32(2), 139-146.

Singh, P., Hansen, K., \& Gupta, S. (2005). Modeling preferences for common attributes in multi-category brand choice. Journal of Marketing Research, 42(2), 195-209

Sriram, S., Chintagunta, P.K., \& Neelamegham, R. (2006). Effects of brand preference, product attributes, and marketing mix variables on technology product markets. Marketing Science, 25(5), 440-456.

Sung, Y., \& Kim, J. (2010). Effects of brand personality on brand trust and brand affect. Psychology and Marketing, 27(7), 639-661.

Swaminathan, V., Stilley, K. M. \& Ahluwalia, R. (2009). When brand personality maters: The moderating role of attachment styles. Journal of Consumer Research, 35(6), 985-1002.

Van Kerckhove, A., Geuens, M., \&Vermier, I. (2012). Intention superiority perspectives on preference-decision consistency.Journal of Business Research, 65(5), 692-700. 
Verhoef, P. C., Lemon, K. N., Parasuraman, A., Roggeveen, A., Tsiros, M., \& Schlesinger, L. A. (2009). Customer experience creation: Determinants, dynamics and management strategies. Journal of Retailing, 85(1), 31-41

Veryzer, R. W. (1993). Aesthetic response and the influence of design principles on product preferences. Advances in Consumer Research, 20, 224-228. Retrieved from http://www.acrweb site.org/volumes/7438/volumes/v20/NA-20

Veryzer, R. W., \& Hutchinson, J. W. (1998). The influence of unity and prototypicality on aesthetic responses to new product designs. Journal of Consumer Research, 24(4), 374-394.

Ward, S., Light, L. \& Goldstine, J. (1999). What high-tech managers need to know what about brands? Harvard Business Review, 77(4), 85-95.

Wong, H.Y., \& Merrilees, B. (2007). Multiple roles for branding in international marketing. International Marketing Review, 24(4), 384-408.

Wrenn, B., Stevens, R. E., \& Loudon, D. L. (2006). Marketing Research: Text and Cases. Routledge.

Zajonc, R. B., \& Markus, H. (1982), Affective and cognitive factors in preferences. Journal of Consumer Research, 9(2), 123-131.

Zarantonello, L., \& Schmitt, B. H. (2010). Using the brand experience scale to profile consumers and predict consumer behavior. Journal of Brand Management, 17(7), $532-540$

Zeithaml, V. (1988) Consumer perceptions of price, quality and value: A means-end model and synthesis of evidence. Journal of Marketing, 52, 2-22.

Zentes, J., Morschett, D., \& Schramm-Klein, H. (2008). Brand personality of retailers an analysis of its applicability and its effect on store loyalty. International Review of Retail, Distribution and Consumer Research, 18(2), 167-184. 